\title{
Ophthalmic Plastic and Reconstructive Surgery
}

\section{Characterising the occluded lacrimal punctum using anterior segment optical coherence tomography \\ --Manuscript Draft--}

\begin{tabular}{|c|c|}
\hline Manuscript Number: & OPRS-D-16-00518R1 \\
\hline Full Title: & $\begin{array}{l}\text { Characterising the occluded lacrimal punctum using anterior segment optical } \\
\text { coherence tomography }\end{array}$ \\
\hline Corresponding Author: & $\begin{array}{l}\text { Hannah M Timlin, BSc FRCOphth } \\
\text { Moorfields Eye Hospital NHS Foundation Trust } \\
\text { London, UNITED KINGDOM }\end{array}$ \\
\hline \multicolumn{2}{|l|}{$\begin{array}{l}\text { Corresponding Author Secondary } \\
\text { Information: }\end{array}$} \\
\hline Corresponding Author's Institution: & Moorfields Eye Hospital NHS Foundation Trust \\
\hline \multicolumn{2}{|l|}{$\begin{array}{l}\text { Corresponding Author's Secondary } \\
\text { Institution: }\end{array}$} \\
\hline \multirow[t]{4}{*}{ Order of Authors: } & Hannah M Timlin, BSc FRCOphth \\
\hline & Pears A Keane, MD, FRCOphth \\
\hline & Geoffrey E Rose, DSc FRCS \\
\hline & Daniel G Ezra, MD FRCOphth \\
\hline \multicolumn{2}{|c|}{ Order of Authors Secondary Information: } \\
\hline Abstract: & $\begin{array}{l}\text { Purpose: Epiphora is sometimes associated with an absent or occluded lacrimal } \\
\text { drainage punctum (or puncta). This study uses non-invasive 'enhanced depth' anterior } \\
\text { segment optical coherence tomography (OCT) to give improved characterisation and } \\
\text { understanding of absent or fully-occluded puncta and the underlying canaliculus. } \\
\text { Methods: Anterior segment spectral domain OCT images were collected prospectively } \\
\text { from } 9 \text { lower puncta of } 6 \text { patients with epiphora and absent or fully-occluded puncta, } \\
\text { not amenable to dilation in clinic, in order to see if a canaliculus was visible on OCT } \\
\text { imaging below the occluded punctum. } \\
\text { Results: An epithelial lined canalicular lumen was visible on OCT in } 4 \text { lower lid puncta } \\
\text { from } 2 \text { patients and OCT identified } 80 \% \text { (4/5) of the canaliculi that were located on } \\
\text { microscope-assisted punctal exploration. These lumen were seen within } 580 \mu \text { depth } \\
\text { from the lid margin surface. A half of the eyes in which a canaliculus was identified on } \\
\text { OCT (the } 2 \text { eyes in a single patient) had resolution of epiphora following punctoplasty, } \\
\text { and the other patient was found to have co-existing nasolacrimal duct stenosis and } \\
\text { required later dacryocystorhinostomy. } \\
\text { The positive predictive value for identifying a canaliculus on lower lid punctal } \\
\text { exploration in acquired complete punctal occlusion (excluding the congenital case) was } \\
1 \text {, with a negative predictive value of } 1 . \\
\text { Conclusion: This study demonstrates that canaliculi can be imaged with OCT where } \\
\text { formal access is precluded by an occluded punctum. This non-invasive investigation } \\
\text { might help predict the likelihood of successful retrieval of a canaliculus at surgical } \\
\text { exploration }\end{array}$ \\
\hline
\end{tabular}




\section{Revision: Response to Reviewers}

\section{Reviewer Comments:}

Reviewer \#1: The authors present their series of obstructed puncta and OCT features of them. I congratulate them for a good work. Few minor issues that needs to be corrected include

1. The term unenterable punctum would not be completely right since it can be entered following the membrane clearance. It is best to replace this term.

This is correct as the puncta were only unenterable in the clinic, even with the use of a nettleship dilator. They were enterable once there was local anaesthetic on board and a sharp instrument. We have changed unenterable to "occluded". This has been changed on lines $1,26,58,70,91,98,182$

2. Many of the references that the authors quoted showed membranes over the punctum clinically and the punctum being not accessible as in the current series secondary to membranes over them, hence to say that this is the first report to be describing these features would not be right. It is suggested to delete the first sentence from the discussion.

We have edited this sentence and changed 'description' to 'OCT images' in line 181.

Reviewer \#3: In the space below, please enumerate specific comments and suggestions, to be shared anonymously with the authors.

this is a very interesting topic designed however; I believe that the number of studied puncta and canaliculi cannot give conclusive data as regards predictability.

We agree that the numbers are small, due to this being an uncommon situation. However, the authors felt that it was useful to discus the predictability as this is what clinicians might find useful for applying to their practice.

We have included..

"Although the number of puncta are small, the positive and negative predictive values have been calculated as an indicator for this small group of patients. Larger numbers of patients would improve the accuracy of these values." In lines 227-229 to make it clear that the numbers are small.

If the editor would prefer us to remove the positive and predictive values, we would be happy to do this under their advice.

Although it gives an idea about the patency of the vertical canaliculus, this 
imaging technique cannot give an idea about the horizontal part which is very challenging and the patency of the vertical part cannot confirm the patency of the distal part. Authors already mentioned that but should elaborate it more in their conclusion

This is a very good point and we have elaborated on this in the text on lines 203207.

"During OCT imaging, it has not been possible to visualize the horizontal canaliculus. This means that with the current OCT machines, it is not possible to assess the patency of the horizontal canaliculus. A patent vertical canaliculus does not necessarily mean that the horizontal canaliculus is patent and illustrates the limit of this mode of investigation currently.

Page 11:

Lines 152- 155 describes where the canalicular lumen was seen from the surface... could you please elaborate what does this signify.

This measurement was used to see the depth that the OCT machine could detect a lumen at rather than having a clinical implication to the outcome of the surgical exploration.

We have inserted 'Currently, with this machine, the deepest lumen detected in this study was that starting at a depth of $301 \mu \mathrm{m}$ from the lid margin surface' in lines 196-197.

Line 160. Do those hyper-reflective foci have any clinical significance or correlation??

We have added this to line 208-213."Currently there is no known clinical significance of the hyper-reflective foci seen within the canaliculus. One possibility is that of make-up debris. However, they have been seen in both women and men. We presume that they represent mucous in the tears. They were noted in both the patients with a patent and non-patent nasolacrimal duct, and so do not appear to be an indicator of nasolacrimal duct patency."

Page 13:

Line 195

You suggested that closed punctum reduces the depth of penetration while in the case with presumed congenital dysgensis, penetration was to 773 um which was higher than in cases you found the canaliculi...I'm a bit confused, could you elaborate please.

This sentence describes closed punctum (in this study) with open puncta (not see in this study, but in other studies of normal puncta). In theory, if a punctum is open (not the case in any of these patients in this publication), then the light from 
the OCT machine will pass through air, whilst inside the punctum and vertical canaliculus. However, in all of the closed puncta in this study, the OCT light had to pass through semi transparent tissue at the lid surface, thus reducing the depth of penetration of the OCT light from the surface of the lid.

Where canaliculi were seen, the depth of the lumen was measured, but the presumed depth of penetration was not measured.

The presumed depth of penetration was only measured in the case where no canaliculus was seen as a guide that perhaps the canaiculus was open at a depth greater than $773 \mu \mathrm{m}$.

To clarify this misunderstanding, we have included "within that depth" in line 172173 , and 'as the OCT light has to pass through the semi transparent tissue of the closed punctum' in lines 199-200.

Reviewer \#4: In the space below, please enumerate specific comments and suggestions, to be shared anonymously with the authors.

Puncta and canaliculi should be labeled with arrows on Figure 3.

This submission only includes 2 figures. There is no clear definition as to where a punctum ends and a canaliculus begins, thus it would be difficult to label these two as separate anatomical areas on a punctum OCT. In these images, the surface of the punctum is closed and we have therefore used the term canaliculus for the lumen seen below this.

\section{OCT in case 5 unhelpful regarding surgery.}

We have added to lines 218-222. "Case 5 did not wish to proceed to surgical exploration. The result of surgical exploration is therefore unknown. However, she represents the clinical presentation of an occluded punctum in the presence of low tear production, and illustrates the presence of epiphora due to dry ocular surface, which was successfully treated with lubricants and not surgery."

The authors feel this this is worthwhile keeping in for completeness for clinicians. However, we will take editorial advice and if you wish us to remove it, we will.

Why a stent in case 4 ?

We have added to lines 214-217 'In case 4, due to the extent of the occlusion and degree of incision, the intraoperative decision was made that the punctum would likely close over during the heeling process. Therefore a Mini Monoka stent was inserted to prevent re-occlusion.'

What kind of stent? 
A Mini Monoka stent was inserted and explained in line 216.

Was there a papilla in case 3 ?

There was no papilla. "No papilla visible" has been inserted into the table on line 291, in column: patient number 3, row: clinical features of lower puncta.

Were both NLD's in case 3 stenotic?

Yes.

We have added 'in both eyes' in line 167 and to the table on line 291, in column: patient number 3, row: improvement in epiphora.

Reviewer Questions and Responses:

Reviewer's Responses to Questions

Title

Is the title adequately descriptive of this article?

Reviewer \#1: No: The term unenterable punctum would not be completely right since it can be entered following the membrane clearance.

Reviewer \#3: Yes

Reviewer \#4: Yes

We have changed this to 'occluded'

\author{
Abstract \\ Does the abstract adequately summarize the contents of this article? If none \\ exists, leave blank and do not answer. \\ Reviewer \#1: Yes \\ Reviewer \#3: Yes \\ Reviewer \#4: Yes
}

\title{
Scientific Quality
}

Comment on whether or not this article adds something new to the scientific literature, or offers a new interpretation or way of thinking about the problem. 
Please be specific and provide details to support your conclusion

Reviewer \#1: This adds more literature to the exisiting scarce literature.

Reviewer \#3: This a very interesting topic where AS-OCT is used in an innovative way to address a common problem that is met in practice especially in my region. this use can be beneficial in many ways.

Reviewer \#4: Too few cases to determine usefulness of this technique relating to surgical outcomes and assign predictive values.

\section{Relevance and Interest to OPRS Readership}

Reviewer \#1: Moderate

Reviewer \#3: High

Reviewer \#4: Moderate

\section{Originality}

Reviewer \#1: Good

Reviewer \#3: Excellent

Reviewer \#4: Good

\section{Technical Accuracy}

Reviewer \#1: Good

Reviewer \#3: Good

Reviewer \#4: Good

\section{Clarity of Presentation}

Reviewer \#1: Good 
Reviewer \#3: Good

Reviewer \#4: Good

\section{Use of English and Grammar}

Reviewer \#1: Good

Reviewer \#3: Excellent

Reviewer \#4: Excellent

\section{Figures}

Are all the tables/figures/illustrations essential? If none exists, leave blank and do not answer.

Reviewer \#1: Yes

Reviewer \#3: Yes

Reviewer \#4: Yes

\section{Tables}

Are tables clearly presented?

Reviewer \#1: Yes

Reviewer \#3: Yes

Reviewer \#4: Yes

Can any of the Tables be eliminated without loss of concept?

Reviewer \#1: No

Reviewer \#3: No 
Reviewer \#4: No

\section{Statistics}

Are statistics used appropriately and accurately?

Reviewer \#1: N/A

Reviewer \#3: N/A

Reviewer \#4: No

\section{References}

Are references adequate and up to date? If none exists, leave blank and do not answer.

Reviewer \#1: Yes

Reviewer \#3: Yes

Reviewer \#4: Yes

Rank this manuscript according to other manuscripts you have reviewed.

Reviewer \#1: Between 90th and 99th percentile (Excellent; definitely publish)

Reviewer \#3: Between 70th and 90th percentile (Good; appropriate to publish if page space allows)

Reviewer \#4: Between 70th and 90th percentile (Good; appropriate to publish if page space allows) 
1 Characterising the occluded lacrimal punctum using anterior

2 segment optical coherence tomography

3

4 Hannah M. Timlin, BSc, FRCOphth, ${ }^{1}$

5 Pearse A. Keane, MD, FRCOphth, ${ }^{2}$

6 Geoffrey E. Rose, DSc, FRCS, 1,2

7 Daniel G. Ezra, MD, FRCOphth ${ }^{1,2}$

$8 \quad{ }^{1}$ Lacrimal Clinic, Moorfields Eye Hospital, London, United Kingdom

$9 \quad{ }^{2}$ NIHR Biomedical Research Centre for Ophthalmology, UCL Institute of

10 Ophthalmology, UK

11

12 Disclosures; Drs. Keane, Rose and Ezra receive some funding from the

13 Department of Health's NIHR Biomedical Research Centre for Ophthalmology at

14 Moorfields Eye Hospital and UCL Institute of Ophthalmology. The views

15 expressed in the publication are those of the authors and not necessarily those of

16 the Department of Health. Dr. Keane has received travel grants from the Allergan

17 European Retina Panel. Dr. Timlin has no conflict of interest.

19 Running Head: OCT imaging of the unenterable lacrimal punctum

21 Correspondence:

22 Mr Daniel G. Ezra, MD FRCOphth, Lacrimal Clinic, Moorfields Eye Hospital

23 London EC1V 2PD, United Kingdom.

24 Tel: +44(0)207 2533411 Fax: +44(0)20 75662334 Email: d.ezra@ucl.ac.uk 
25 Precis: An epithelial lined canalicular lumen was visible on OCT in 4 lower lid

26 puncta from 2 patients with occluded puncta, identifying $80 \%(4 / 5)$ of the

27 canaliculi that were located on microscope-assisted surgical punctal exploration.

32 Word Count: 1333

34 Figures: 2

36 Tables: 1

38 Abbreviations:

39 OCT - optical coherence tomography

$40 \quad$ EDI - enhanced depth imaging

41 ASM - anterior segment module

$42 \quad$ IR - infrared

43 HEYEX - Heidelberg Eye Explorer

45 Keywords: Lacrimal punctum, lacrimal canaliculus, epiphora, optical coherence

46 tomography, non-invasive. 


\section{ABSTRACT}

50 Purpose: Epiphora is sometimes associated with an absent or occluded lacrimal

51 drainage punctum (or puncta). This study uses non-invasive 'enhanced depth'

52 anterior segment optical coherence tomography (OCT) to give improved

53 characterisation and understanding of absent or fully-occluded puncta and the

54 underlying canaliculus.

55 Methods: Anterior segment spectral domain OCT images were collected

56 prospectively from 9 lower puncta of 6 patients with epiphora and absent or fully-

57 occluded puncta, not amenable to dilation in clinic, in order to see if a canaliculus

58 was visible on OCT imaging below the occluded punctum.

59 Results: An epithelial lined canalicular lumen was visible on OCT in 4 lower lid

60 puncta from 2 patients and OCT identified $80 \%(4 / 5)$ of the canaliculi that were

61 located on microscope-assisted punctal exploration. These lumen were seen

62 within $580 \mu \mathrm{m}$ depth from the lid margin surface. A half of the eyes in which a

63 canaliculus was identified on OCT (the 2 eyes in a single patient) had resolution

64 of epiphora following punctoplasty, and the other patient was found to have co-

65 existing nasolacrimal duct stenosis and required later dacryocystorhinostomy.

66 The positive predictive value for identifying a canaliculus on lower lid punctal

67 exploration in acquired complete punctal occlusion (excluding the congenital

68 case) was 1 , with a negative predictive value of 1 .

69 Conclusion: This study demonstrates that canaliculi can be imaged with OCT

70 where formal access is precluded by an occluded punctum. This non-invasive 
71 investigation might help predict the likelihood of successful retrieval of a

72 canaliculus at surgical exploration

73 


\section{INTRODUCTION}

75 Epiphora is a common presenting symptom and may rarely be due to an

76 absent or occluded lacrimal punctum (puncta) - this being either congenital

77 absence or due to a range of acquired conditions causing complete fibrosis. In

78 either the congenital or acquired form, there can be either isolated punctal

79 occlusion (with a healthy underlying canaliculus), or else a concomitant

80 canalicular stenosis or occlusion along some or all of its length ${ }^{1}$. Whereas a

81 healthy canaliculus may allow normal tear drainage after punctoplasty, underlying

82 canalicular narrowing means that punctoplasty alone is unlikely to be successful

83 in addressing epiphora; the latter patients should be warned that canaliculo-

84 dacryocystorhinostomy (cDCR) or insertion of a canalicular bypass tube might be

85 required for symptomatic control., 1,2

86 Punctal occlusion may be secondary to aging, chronic inflammation

87 (blepharitis, mucous membrane pemphigoid), infections (herpes viruses,

88 trachoma), chronic topical therapy (glaucoma drops, mitomycin-C), systemic

89 medications (5-flourouracil and Paclitaxel), or systemic diseases (such as

90 cutaneous porphyria, lichen planus), local radiation, or trauma. ${ }^{3}$ When an

91 occluded punctum is seen in clinic, it is impossible to determine whether a

92 healthy underlying canaliculus is present and, thereby, the prognosis for

93 punctoplasty. In some cases of congenital punctal agenesis, the presence of a

94 lacrimal papilla, a dimple ${ }^{4}$ or a darker visible area behind a semi-transparent

95 membrane may suggest a patent underlying canaliculus. 
Anterior segment OCT has been used to describe healthy puncta. 5, 6, 7, 8

97 We report the application of spectral domain OCT with an anterior segment

98 module, using EDI scanning protocols, for in vivo assessment of the occluded

99 lacrimal punctum and associated canaliculus, together with the outcome for

100 punctoplasty.

101

102 MATERIALS AND METHODS

103 Subjects and ethics.

$104 \quad$ Six patients with epiphora and one or more occluded lower lid puncta were

105 recruited prospectively over a year. Written informed consent was obtained from

106 all subjects and Regional Ethics Committee approval was obtained (LREC ref:

107 14/LO/1450; 153332 Westminster NRES Committee). Information regarding age,

108 gender, and ethnicity, was obtained for all participants.

109 Image acquisition protocol.

$110 \quad$ Previously-described imaging protocols were used ${ }^{5}$ and OCT image-sets

111 of both lower lacrimal puncta were obtained by a single operator (H.T.), using a

112 single Spectralis OCT device with "Anterior Segment Module" (ASM) (Heidelberg

113 Engineering, Germany). The ASM consists of an add-on lens and dedicated

114 software, and acquires 40,000 A-scans per second with a $7 \mu \mathrm{m}$ axial resolution in

115 tissue, and a transverse resolution of $14 \mu \mathrm{m}$. All images for this study were

116 acquired using the scleral setting, a mode in which EDI-OCT can be performed.

117 Each cross-sectional image subtended a 15을 angle (eyelid length of $\sim 8 \mathrm{~mm}$ ), the

118 brightness set to $25 \%$, and single scans were acquired with the automated real 
119 time (ART) set to between 2 and 20 frames - that is, each image comprising the

120 average of between 2 and 20 B-scans. Images were acquired at a working

121 distance of about $12 \mathrm{~mm}$.

122 Each participant was firmly positioned in the OCT headrest. With both

123 eyes open, the lower lid margin was everted (using a cotton bud, gently placed

124 below the punctum and rolled to evert it) into a plane perpendicular to the light

125 source. The long axis of scan acquisition was rotated to parallel the lid margin

126 and multiple OCT and infrared (IR) images were obtained for each peripunctal

127 area.

128 Qualitative and Quantitative Image Analysis

129 The OCT image-sets were evaluated for several morphological

130 characteristics. Measurements were taken using Heidelberg Eye Explorer

131 (HEYEX) software (version 1.6.8).

\section{Positive and Negative predictive values}

133 Positive predictive values were calculated to show the chances of locating

134 the canaliculus during surgical exploration in those who had lumen visible on

135 OCT. Negative predictive values were calculated to show the chances of not

136 finding a canaliculus during exploration when no lumen was seen on OCT.

\section{RESULTS}

139 Using anterior segment OCT, 9 unenterable lower puncta were imaged in

1406 patients (5 female; 83\%) - 3 bilateral (Figure 1) and 3 unilateral (Figure 2); 4/6 
141 patients were Caucasians and the average age was 48.5 years (range 26-66)

142 (Table 1).

143 Clinical details

$144 \quad$ Epiphora had been present from between 1 and 26 years. Three patients

145 had significant chronic blepharitis, 1 had atopic conjunctivitis, and 1 had keratitis

146 sicca due to rheumatoid arthritis. Local conjunctival scarring, with occlusive

147 punctal membranes, was visible in 4 lower lids of 2 patients (Figures 1C, D, K \&

148 L).

149 Punctal optical coherence tomography findings

150 A definite epithelial-lined lumen was visible beneath the occluded puncta

151 in 4 lids from 2 patients (Patients 2 \& 3; Figures 1E, F, I and J).

152 Patient 2's canalicula lumens were seen between the depth of $301 \mu \mathrm{m}$ and

$153405 \mu \mathrm{m}$ on the right and between $266 \mu \mathrm{m}$ and $580 \mu \mathrm{m}$ in the left. Patient 3's

154 canalicula lumens were seen between the depth of $126 \mu \mathrm{m}$ and $293 \mu \mathrm{m}$ on the

155 right and between $129 \mu \mathrm{m}$ and $302 \mu \mathrm{m}$ in the left.

156 The lumen sizes on OCT images were measured horizontally and

157 vertically showing sizes of; $251 \mu \mathrm{m}$ by $43 \mu \mathrm{m}$ in patient 2's right eye, $580 \mu \mathrm{m}$ by

$158310 \mu \mathrm{m}$ in patient 2's left eye, $413 \mu \mathrm{m}$ by $61 \mu \mathrm{m}$ in patient 3's right eye, and $517 \mu \mathrm{m}$

159 by $91 \mu \mathrm{m}$ in patient 3's left eye respectively.

160 Hyperreflectve foci were seen within two of the lumen seen on OCT

161 (Figure 1F and J).

162 Outcomes following punctal exploration 
Eight of the 9 puncta underwent punctal exploration under local

164 anaesthesia and canaliculi were located in the 4 puncta (2 patients) where an

165 epithelial-lined lumen was visible of OCT. Symptom resolution (bilateral) was

166 achieved in one patient and, in the other, there was clinical evidence of

167 nasolacrimal duct stenosis after the punctoplasty in both eyes.

168 Where OCT failed to detect a canalicular lumen, surgical exploration

169 identified a lumen in only one of the four cases (Patient 4); this patient had life-

170 long epiphora, perhaps suggesting punctal dysgenesis, rather than an acquired

171 occlusion. In this patient the OCT scan appeared to penetrate to a depth of

$172773 \mu \mathrm{m}$ from the eyelid margin surface, without identifying a lumen within that

173 depth.

174 Where symptoms were acquired (excluding Case 4), the positive

175 predictive value for identifying a canaliculus on lower lid punctal exploration after

176 OCT was 1 , with a negative predictive value of 1 ; if the congenital case (Case 4)

177 is included, the positive predictive value was 1 and negative predictive value was

$178 \quad 0.75$.

179

\section{DISCUSSION}

181 This appears to be the first OCT images of an epithelial-lined canalicular

182 lumen in the presence of an occluded punctum. Although an OCT has been

183 reported in a 14 year old with a congenital punctal membrane, imaging only

184 demonstrated the proximal part of the vertical ampullary walls ${ }^{9}$ and not an

185 epithelial-lined lumen; this probably reflects the different OCT scanner used 
186 (RTVue scanner, Optovue). The Spectralis used in this study not only had 187 considerably greater penetration, but also had higher resolution - the latter

188 allowing definition of a separate layer lining the lumen (presumed to be

189 epithelium) and reinforcing canalicular identification. In our one patient with congenital epiphora, the failure to show the

191 canaliculus (later found at surgery) with OCT suggests that this congenital

192 canalicular anomaly might be sited too deeply $(>773 \mu \mathrm{m})$ for the OCT penetration

193 -- it possibly being an imperforate punctum rather than superficial membrane. ${ }^{10}$

194 More subjects are needed particularly in congenital cases to ascertain the

195 maximum depth at which a canaliculus can be identified when scanning through

196 a closed punctum. Currently, with this machine, the deepest lumen detected in

197 this study was that starting at a depth of $301 \mu \mathrm{m}$ from the lid margin surface. It is

198 highly likely that a closed punctum reduces the depth of OCT penetration when

199 compared to an open punctum, as the OCT light has to pass through the semi

200 transparent tissue of the closed punctum. With the emergence of intraoperative

201 OCT, there may be scope in the future to use our proposed method to guide

202 surgeons during initially unsuccessful punctal exploration intraoperatively.

203 During OCT imaging, it has not been possible to visualize the horizontal

204 canaliculus. This means that with the current OCT machines, it is not possible to

205 assess the patency of the horizontal canaliculus. A patent vertical canaliculus

206 does not necessarily mean that the horizontal canaliculus is patent and illustrates

207 the limit of this mode of investigation currently. 
Currently there is no known clinical significance of the hyper-reflective foci

209 seen within the canaliculus. One possibility is that of make-up debris. However,

210 they have been seen in both women and men. ${ }^{5}$ We presume that they represent

211 mucous in the tears. They were noted in both the patients with a patent and non-

212 patent nasolacrimal duct, and so do not appear to be an indicator of nasolacrimal

213 duct patency.

214 In case 4, due to the extent of the occlusion and degree of incision, the

215 intraoperative decision was made that the punctum would likely close over during

216 the heeling process. Therefore, a Mini Monoka stent was inserted to prevent re-

217 occlusion.

218 Case 5 did not wish to proceed to surgical exploration. The result of

219 surgical exploration is therefore unknown. However, she represents the clinical

220 presentation of an occluded punctum in the presence of low tear production, and

221 illustrates the presence of epiphora due to dry ocular surface, which was

222 successfully treated with lubricants and not surgery.

223 This study has shown that, in patients with occluded lower puncta, OCT

224 can clearly identify an epithelial-lined canaliculus in $4 / 5$ cases where a

225 canaliculus was later identified at surgery; the one case of failed preoperative

226 identification was probably a congenital anomaly with life-long symptoms.

227 Although the number of puncta are small, the positive and negative predictive

228 values have been calculated as an indicator for this small group of patients.

229 Larger numbers of patients would improve the accuracy of these values. This

230 study suggests that OCT might usefully predict the likely success of punctal 
231 exploration in patients with acquired punctal occlusion, with the absence of a 232 lumen on OCT guiding initiation of a discussion on the potential need for CDCR

233 surgery or insertion of a canalicular bypass tube for symptomatic control.

\section{REFERENCES}

237 1. McNAB A.A. 1998. Lacrimal canalicular obstruction associated with topical ocular medication. Aust NZ J Ophthalmol. Aug;26(3):219-23.

2. METAIREAU J.P. 1988. Treatment of canalicular block. Eye 12(2):220-222.

3. SOIBERMAN U. KAKIZAKI H. SELVA D. LEIBOVITCH I. 2012. Punctal stenosis: definition, diagnosis, and treatment. Clinical Ophthalmology. 6 10111018.

4. ALI M.J. NAIK M.N. 2014. Incomplete punctual canalization -a balloon variant of the external membrane: a case report. Journal of Medical Case Reports, 8:120.

5. TIMLIN H.M. KEANE P.A. DAY A.C. SALAM T. ABDULLAH M. ROSE G.E. EZRA D.G. 2016. Characterizing the lacrimal punctal region using anterior segment optical coherence tomography. Acta Ophthalmologica 94:154-159.

6. ALLAM, R.S.H.M. AHMED, R.A. 2015. Evaluation of the Lower Punctum Parameters and Morphology Using Spectral Domain Anterior Segment Optical Coherence Tomography. Journal of Ophthalmology Article ID 591845, 7 pages, 2015. doi:10.1155/2015/591845.

7. KAMAL, S. ALI, M. J. ALI, M.H. NAIK, M. 2015. Fourier Domain Optical Coherence Tomography With 3D and En Face Imaging of the Punctum and 
Vertical Canaliculus: A Step Toward Establishing a Normative Database. Ophthal $255 \quad$ Plast Reconstr Surg, Published ahead of print.

256 8. WAWRZYNSKI, J. R., SMITH, J., SHARMA, A. \& SALEH, G. M. 2014.

257 Optical Coherence Tomography Imaging of the Proximal Lacrimal System. Orbit, $258 \quad 1-5$.

259 9. KAMAL, S. ALI, M. J. ALI, M.H. NAIK, M. 2015. Incomplete Punctal

260 Canalization: Report of Fourier Domain Optical Coherence Tomography

$261 \quad$ Features. Ophthalmic Plastic \& Reconstructive Surgery 31 (3) 251-2.

262 10. ALI M.J. MOHAPATRA S. MULAY K. NAIK M.N. HONAVAR S.G. 2013.

263 Incomplete punctual canalization: the external and internal punctual membranes.

264 Outcomes of membranotomy and adjunctive procedures. Br J Ophthalmol 97:92-

26595.

266 
269 Figure 1: Optical coherence tomographic (OCT) and infrared (IR) images of

270 three patients with bilaterally unenterable lower lacrimal puncta: Patient 1 (A

271 Right OCT; B Left OCT; C Right IR; D Left IR), Patient 2 (E Right OCT; F Left

272 OCT; G Right IR; H Left IR) and Patient 3 (I Right OCT; J Left OCT; K Right IR; L

273 Left IR).

274

275 Figure 2: Optical coherence tomographic (OCT) and infrared (IR) images of

276 three patients with unilateral unenterable lower lacrimal puncta: Patient 4 right

277 eye (A OCT; B IR), Patient 5 left eye (C OCT; D IR), Patient 6 left eye (E OCT; F $278 \quad \mathrm{IR})$.

280 TABLE LEGEND

282 Table 1: Demographics and outcomes of 6 patients with unenterable lower

283 lacrimal puncta who underwent peripunctal OCT 


\begin{tabular}{|c|c|c|c|c|c|c|}
\hline \multirow{2}{*}{ Characteristic } & \multicolumn{6}{|c|}{ Patient number } \\
\hline & 1 & 2 & 3 & 4 & 5 & 6 \\
\hline Gender & Female & Female & Female & Female & Female & Male \\
\hline Age (years) & 44 & 40 & 66 & 26 & 49 & 66 \\
\hline Ethnicity & Caucasian & Indian & Asian & Caucasian & Caucasian & Caucasian \\
\hline Laterality & Bilateral & Bilateral & Bilateral & Right & Left & Left \\
\hline $\begin{array}{l}\text { Duration of } \\
\text { epiphora }\end{array}$ & $2-3$ years & 3-5 years & 1 year & $\begin{array}{l}\text { Life-long } \\
\text { (26 years) }\end{array}$ & $3-4$ years & $4-5$ years \\
\hline $\begin{array}{l}\text { Relevant } \\
\text { ocular or } \\
\text { medical } \\
\text { history }\end{array}$ & Blepharitis & $\begin{array}{l}\text { Hayfever } \\
\text { Atopic } \\
\text { conjunctivitis }\end{array}$ & $\begin{array}{c}\text { Treated } \\
\text { primary } \\
\text { hypothyroidism }\end{array}$ & None & $\begin{array}{c}\text { Blepharitis } \\
\text { Rheumatoid } \\
\text { arthritis; left } \\
\text { keratitis } \\
\text { sicca } \\
\text { (Schirmer's } \\
5 \mathrm{~mm} \text { left, } \\
\text { 14mm right) }\end{array}$ & $\begin{array}{c}\text { Blepharitis } \\
\text { Rosacea }\end{array}$ \\
\hline $\begin{array}{c}\text { Clinical } \\
\text { features of } \\
\text { upper puncta }\end{array}$ & $\begin{array}{l}\text { Patent to } \\
\text { syringing }\end{array}$ & $\begin{array}{l}\text { Stenotic, but } \\
\text { patent after } \\
\text { dilation }\end{array}$ & $\begin{array}{l}\text { Patent to } \\
\text { syringing }\end{array}$ & $\begin{array}{l}\text { No visible } \\
\text { punctum }\end{array}$ & Unrecorded & Unrecorded \\
\hline $\begin{array}{c}\text { Clinical } \\
\text { features of } \\
\text { lower puncta }\end{array}$ & $\begin{array}{l}\text { Conjunctival } \\
\text { scarring } \\
\text { with } \\
\text { membrane }\end{array}$ & $\begin{array}{l}\text { No visible } \\
\text { punctum; } \\
\text { papilla } \\
\text { present }\end{array}$ & $\begin{array}{l}\text { Conjunctival } \\
\text { scarring with } \\
\text { membrane, no } \\
\text { papilla visible }\end{array}$ & $\begin{array}{l}\text { No visible } \\
\text { punctum, } \\
\text { dimple or } \\
\text { translucent } \\
\text { membrane }\end{array}$ & $\begin{array}{l}\text { No visible } \\
\text { punctum; } \\
\text { papilla } \\
\text { present }\end{array}$ & $\begin{array}{l}\text { No visible } \\
\text { punctum }\end{array}$ \\
\hline $\begin{array}{c}\text { Lower } \\
\text { punctal OCT }\end{array}$ & $\begin{array}{l}\text { No visible } \\
\text { canaliculi }\end{array}$ & $\begin{array}{l}\text { Epithelial- } \\
\text { lined lumen } \\
\text { visible } \\
\text { bilaterally }\end{array}$ & $\begin{array}{l}\text { Epithelial-lined } \\
\text { lumen visible } \\
\text { bilaterally }\end{array}$ & $\begin{array}{l}\text { No visible } \\
\text { canaliculus }\end{array}$ & $\begin{array}{l}\text { No visible } \\
\text { canaliculus }\end{array}$ & $\begin{array}{l}\text { No visible } \\
\text { canaliculus }\end{array}$ \\
\hline $\begin{array}{l}\text { Lower } \\
\text { punctal } \\
\text { exploration }\end{array}$ & $\begin{array}{l}\text { Canaliculi } \\
\text { not located }\end{array}$ & $\begin{array}{l}\text { Canaliculi } \\
\text { located, with } \\
\text { punctoplasty } \\
\text { performed }\end{array}$ & $\begin{array}{l}\text { Canaliculi } \\
\text { located, with } \\
\text { punctoplasty } \\
\text { performed }\end{array}$ & $\begin{array}{l}\text { Upper and } \\
\text { lower } \\
\text { canaliculi } \\
\text { located } \\
\text { and } \\
\text { stented }\end{array}$ & $\begin{array}{l}\text { Not } \\
\text { performed } \\
\text { due to dry } \\
\text { eye }\end{array}$ & $\begin{array}{l}\text { Canaliculus } \\
\text { not located }\end{array}$ \\
\hline $\begin{array}{l}\text { Improvement } \\
\text { in epiphora }\end{array}$ & $\begin{array}{l}\text { Persistent } \\
\text { symptoms }\end{array}$ & Cured & $\begin{array}{c}\text { Persistent } \\
\text { symptoms; } \\
\text { nasolacrimal } \\
\text { duct stenosis } \\
\text { demonstrated } \\
\text { on syringing in } \\
\text { both eyes }\end{array}$ & $\begin{array}{l}\text { Cured after } \\
\text { stent } \\
\text { removal }\end{array}$ & $\begin{array}{l}\text { Cured with } \\
\text { long-term } \\
\text { lubricants }\end{array}$ & $\begin{array}{l}\text { Persistent } \\
\text { symptoms }\end{array}$ \\
\hline
\end{tabular}


298 Acknowledgements

299 Dr Hannah Timlin had full access to all of the data in the study and takes

300 responsibility for the integrity of the data and the accuracy of the data analysis. 
Precis: An epithelial lined canalicular lumen was visible on OCT in 4 lower lid puncta from 2 patients with occluded puncta, identifying $80 \%$ (4/5) of the canaliculi that were located on microscope-assisted surgical punctal exploration. 

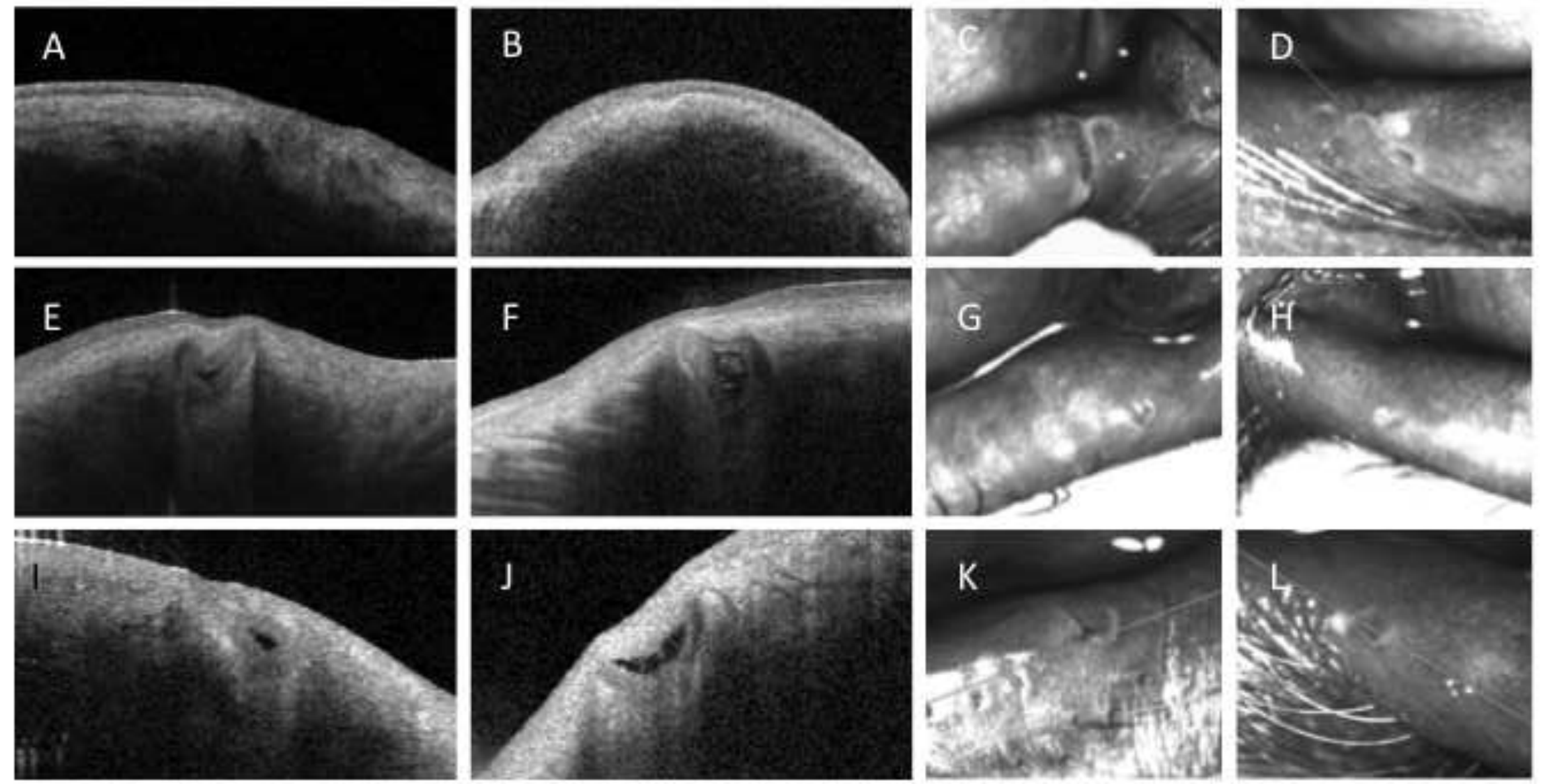

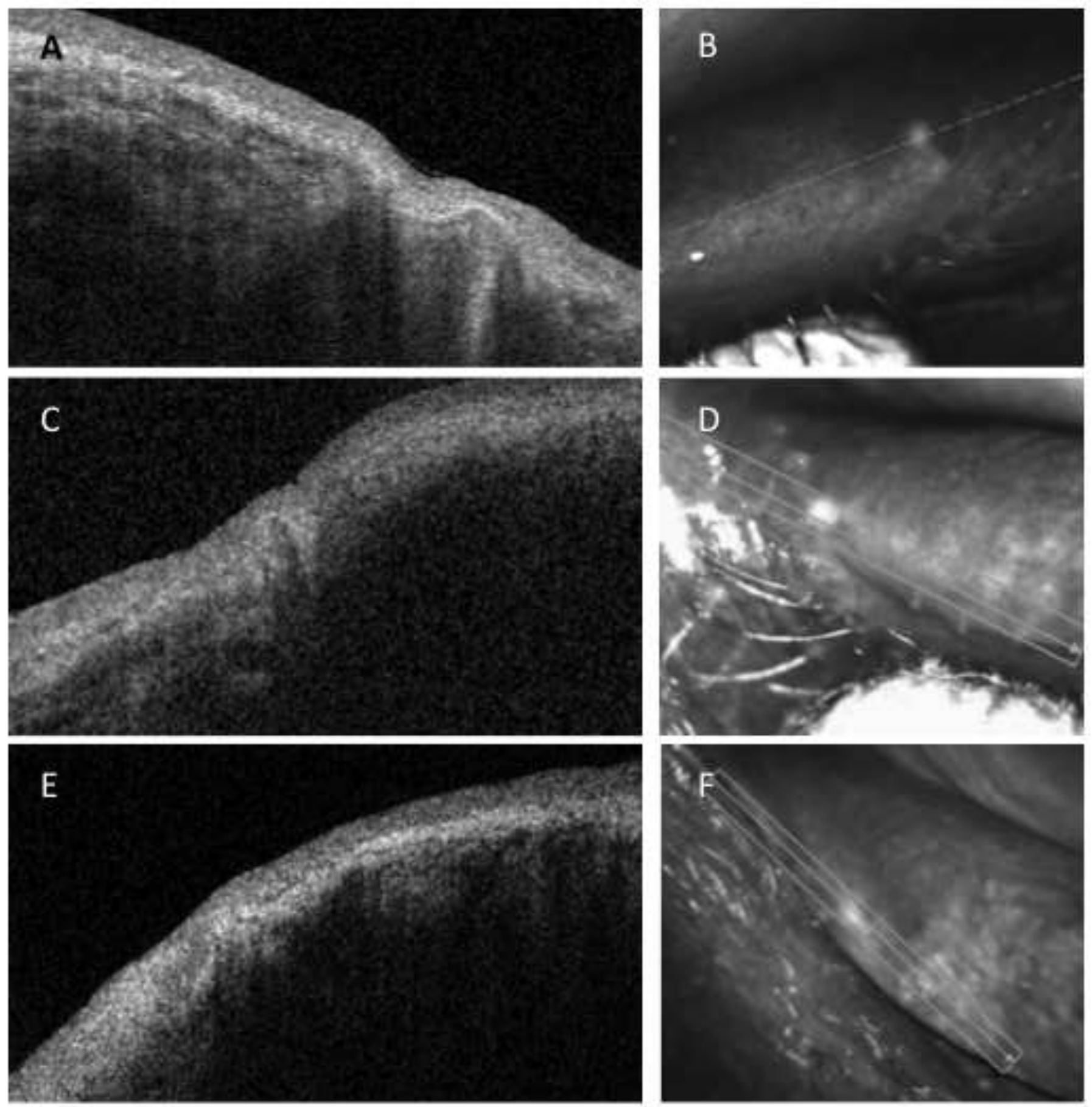


\begin{tabular}{|c|c|c|c|c|c|c|}
\hline \multirow{2}{*}{ Characteristic } & \multicolumn{6}{|c|}{ Patient number } \\
\hline & 1 & 2 & 3 & 4 & 5 & 6 \\
\hline Gender & Female & Female & Female & Female & Female & Male \\
\hline Age (years) & 44 & 40 & 66 & 26 & 49 & 66 \\
\hline Ethnicity & Caucasian & Indian & Asian & Caucasian & Caucasian & Caucasian \\
\hline Laterality & Bilateral & Bilateral & Bilateral & Right & Left & Left \\
\hline $\begin{array}{c}\text { Duration of } \\
\text { epiphora }\end{array}$ & 2-3 years & $3-5$ years & 1 year & $\begin{array}{l}\text { Life-long } \\
\text { (26 years) }\end{array}$ & 3-4 years & $4-5$ years \\
\hline $\begin{array}{c}\text { Relevant } \\
\text { ocular or } \\
\text { medical } \\
\text { history }\end{array}$ & Blepharitis & $\begin{array}{c}\text { Hayfever } \\
\text { Atopic } \\
\text { conjunctivitis }\end{array}$ & $\begin{array}{c}\text { Treated } \\
\text { primary } \\
\text { hypothyroidism }\end{array}$ & None & $\begin{array}{l}\text { Blepharitis } \\
\text { Rheumatoid } \\
\text { arthritis; left } \\
\text { keratitis } \\
\text { sicca } \\
\text { (Schirmer's } \\
5 \mathrm{~mm} \text { left, } \\
14 \mathrm{~mm} \text { right) }\end{array}$ & $\begin{array}{c}\text { Blepharitis } \\
\text { Rosacea }\end{array}$ \\
\hline $\begin{array}{c}\text { Clinical } \\
\text { features of } \\
\text { upper puncta }\end{array}$ & $\begin{array}{l}\text { Patent to } \\
\text { syringing }\end{array}$ & $\begin{array}{l}\text { Stenotic, but } \\
\text { patent after } \\
\text { dilation }\end{array}$ & $\begin{array}{l}\text { Patent to } \\
\text { syringing }\end{array}$ & $\begin{array}{l}\text { No visible } \\
\text { punctum }\end{array}$ & Unrecorded & Unrecorded \\
\hline $\begin{array}{c}\text { Clinical } \\
\text { features of } \\
\text { lower puncta }\end{array}$ & $\begin{array}{l}\text { Conjunctival } \\
\text { scarring } \\
\text { with } \\
\text { membrane }\end{array}$ & $\begin{array}{l}\text { No visible } \\
\text { punctum; } \\
\text { papilla } \\
\text { present }\end{array}$ & $\begin{array}{l}\text { Conjunctival } \\
\text { scarring with } \\
\text { membrane, no } \\
\text { papilla visible }\end{array}$ & $\begin{array}{l}\text { No visible } \\
\text { punctum, } \\
\text { dimple or } \\
\text { translucent } \\
\text { membrane }\end{array}$ & $\begin{array}{l}\text { No visible } \\
\text { punctum; } \\
\text { papilla } \\
\text { present }\end{array}$ & $\begin{array}{l}\text { No visible } \\
\text { punctum }\end{array}$ \\
\hline $\begin{array}{c}\text { Lower } \\
\text { punctal OCT }\end{array}$ & $\begin{array}{l}\text { No visible } \\
\text { canaliculi }\end{array}$ & $\begin{array}{l}\text { Epithelial- } \\
\text { lined lumen } \\
\text { visible } \\
\text { bilaterally }\end{array}$ & $\begin{array}{c}\text { Epithelial-lined } \\
\text { lumen visible } \\
\text { bilaterally }\end{array}$ & $\begin{array}{l}\text { No visible } \\
\text { canaliculus }\end{array}$ & $\begin{array}{l}\text { No visible } \\
\text { canaliculus }\end{array}$ & $\begin{array}{l}\text { No visible } \\
\text { canaliculus }\end{array}$ \\
\hline $\begin{array}{c}\text { Lower } \\
\text { punctal } \\
\text { exploration }\end{array}$ & $\begin{array}{c}\text { Canaliculi } \\
\text { not located }\end{array}$ & $\begin{array}{l}\text { Canaliculi } \\
\text { located, with } \\
\text { punctoplasty } \\
\text { performed }\end{array}$ & $\begin{array}{l}\text { Canaliculi } \\
\text { located, with } \\
\text { punctoplasty } \\
\text { performed }\end{array}$ & $\begin{array}{l}\text { Upper and } \\
\text { lower } \\
\text { canaliculi } \\
\text { located } \\
\text { and } \\
\text { stented }\end{array}$ & $\begin{array}{l}\text { Not } \\
\text { performed } \\
\text { due to dry } \\
\text { eye }\end{array}$ & $\begin{array}{l}\text { Canaliculus } \\
\text { not located }\end{array}$ \\
\hline $\begin{array}{l}\text { Improvement } \\
\text { in epiphora }\end{array}$ & $\begin{array}{l}\text { Persistent } \\
\text { symptoms }\end{array}$ & Cured & $\begin{array}{c}\text { Persistent } \\
\text { symptoms; } \\
\text { nasolacrimal } \\
\text { duct stenosis } \\
\text { demonstrated } \\
\text { on syringing in } \\
\text { both eyes }\end{array}$ & $\begin{array}{c}\text { Cured after } \\
\text { stent } \\
\text { removal }\end{array}$ & $\begin{array}{l}\text { Cured with } \\
\text { long-term } \\
\text { lubricants }\end{array}$ & $\begin{array}{l}\text { Persistent } \\
\text { symptoms }\end{array}$ \\
\hline
\end{tabular}

